\title{
Ethnicity, Identity, And The Politics Of Space In Urban Society of Jayapura City
}

\author{
Akhmad \\ Rosye H.R Tanjung \\ Agustina Ivon Poli
}

Aisyah Ali

Nindyo B. Kumoro

\begin{abstract}
Despite the Special Autonomy Law has been declared, ethnical sentiment between migrant settlers (amber) and indigenous of Papua (komin) is still strong in Jayapura society. This study assumes that primordial sentiment does not merely derive from cultural differences, yet it is more likely caused by the social-economical disparities, mainly access to the venture space resources. Thereby, this study attempts to investigate how economic spatial domination upon Jayapura city between settlers and Papuans and what are the affecting factors? Using the urban ethnography method, we argue that settlers-indigenous sentiment grew as urban economic structure had not been really changed since the colonial era, even until Special Autonomy implementation. Those settlers such Chinese, Buginese, or Javanese subdue economical opportunities of the city. While Papua communities have not fully integrated to the market economy due to political history which tied up to the traditional manner. However, state affirmative politic after the Special Autonomy Law symbolically delivers new strength for Papuans in negotiating towards economic space disparities of Jayapura.
\end{abstract}

Keywords: Informal economic, space, ethnic, dual economy, affirmative politic

\section{INTRODUCTION}

The city of Jayapura as a province capital has been flourishing as the center of economy and politic, even towards the entire land of Papua. It becomes a destination of immigrants groups from different ethnics in Indonesia and no wonder this place has become a region with the highest ethnic diversity in Papua (Ananta et al, 2016). Chinese, Javanese, Buginese, Butonese, Makassarese and others basically had have lived many decades, interacting to Papua communities and became Jayapura inhabitants, mainly right after Papua integrated to the Republic of Indonesia in 1963. But, identity polarization between settlers and indigenous of Papua seems still remains nowadays. Identity sentiment about who is who between migrants and indigenous is reflected in daily conversation when mentioning amber (physically straighthaired) refers to comers and komin (curly-haired) for indigenous (Akhmad, 2005; Widjojo et al, 2008).

The terms of amber and komin do not only merely related to cultural identity difference but also strongly related to social-economical and political within society. Danilyn Rutherford (Chauvel, 2007:44) once argued about amberi term is also linked towards social economical class identity. In Dutch colonial era, this term not only applied to Western people or Non-Papua Indonesians, 'amberi' was also used for Papua elite groups such government officials, teachers, 
traders, and other educated groups which were considered as an accomplice of the colonialist. Apparently, Rutherford's statement is quite relevant in perceiving Jayapura society today, which amber-komin identities polarization could not be separated from the urban economic structure and social class.

This article intends to examine how settlers and indigenous identity emerges in the economic structure of Jayapura. Earlier, there are some articles which classified Jayapura city based on the spatial perspective of ethnic and social class (Jones dan Suhartini, 2014; Baharuddin et al, 2015). Those studies concerned on how settlements in Jayapura divided into social classes (elite, countryside, fisherman, etc.), migrants ethnics (Chinese, Ambonese, Buginese, Makassarese, Javanese, etc.) and indigenous Papuans (whether Papuan ethnics from Jayapura or other areas) (Baharuddin et al, 2015). One thing that should be investigated further beside settlement space matter is economical contestation in the use of venture spaces within Jayapura. It happens since Jayapura accommodates numerous settlers yet has limited economical resources (Akhmad, 2005). Jayapura depends on the formal sector such as government officials and private offices which afford few opportunities both for migrants and Papuans (McGibbon, 2004). Hence, the real economic competition between settlers and indigenous ethnics will likely occur eventually within the small entrepreneurship sectors, such as trade and service, marketplaces, street vendors, and other informal sectors. In other words, this study investigates how economical domination in Jayapura city among settlers and indigenous ethnics that later strengthen primordial sentiment?

In observing this issue, something that cannot be neglected is the appearance of Special Autonomy (Otsus) Law which was declared in 2001. The discourse about who is Orang Asli Papua/ indigenous Papuans (OAP) started to be spoken frequently whether openly or silently, in daily activities and public policy (Al-Hamid et al, 2013). In one hand, political identity of Papua which is getting stronger and identity affirmative policy in favor of Papua by government indeed contributes in polarizing those amber and komin ethnic groups, but in the other hand reinforces Papuan society in economical contestation in the presence of migrants.

\section{Ethnicity, Dual Economy, and Affirmative Politic within Urban Space}

Similar to other cities in Papua, Jayapura is a frontier for people from other regions within Indonesia as a new economic potential. Riwanto Tirtosudarmo (2014) states that migration into Papua is not a recent matter; it has occurred prior to the European colonial era. Papuan society has been building intensive interaction over nearby islands of Maluku within thousands of years (mainly Tidore), which continued until the Colonial era (Upton, 2009). The key point in social landscape shift due to migration could be marked since West Papua had become part of Indonesia in 1963. From that moment until 1990s Indonesian government had promoted establishment policy towards Papua that drew urban settlement expansion, economic growth in mining and non-mining sectors, transportation infrastructure development, transmigration, and migrants entrance, particularly from Java and East Indonesia region (McGibbon, 2004).

Those migrants, according to Gamaut and Manning (1979:49), consisting of three groups; (1) government officers and experts as well as big corporations employees that entered Papua; (2) farmers who were brought from Java for government transmigration program; (3) spontaneous migrants who moved at their own expense independently and expected for a prosperous job or trading in Papua. Those who migrated brought various social and cultural attributes. These attributes emerge as cultural identity when encountering different groups with different attributes. This had made a group becomes an ethnic group. The term of ethnicity in this study is defined as a social construct that reflects cultural identity as a group 
attribute or a society is not permanently static but changeable depends on the circumstance (Barth, 1988). Therefore, ethnicity is situational-contextual and it is something can be constructed or reconstructed associated to group needs or related group (Tirtosudarmo, 2014:2).

In this study, the context that hardens the construction of the ethnic identity boundaries of who are immigrants (amber) and who are indigenous (komin) is the matter of socio-economic disparities in Jayapura. Migrants from South Sulawesi (mainly from Bugis, Buton, and Makassar), Java, Madura, Toraja or even Chinese Indonesian had long dominated financial circle over the marketplace and urban entrepreneurship ventures. Only a few indigenous elites of Papua possess skills and qualification and decide to be in bureaucracy sector, most indigenous did not possess skills and had been marginalized in their own land, especially in the terms of entrepreneurship (Lekitoo via Baharuddin et al, 2015; Widjojo et al, 2008; Chauvel, 2007; McGibbon, 2004).

Kinds of literature indicate that at least three significant things which lead Papuans into leftbehind community economically and entrepreneurship. Firstly, from experiences that have been formed historically and politically. Migrants (mainly Chinese) were first settlers who dominated goods trade since Jayapura was established as a Dutch military base. During the integration process of West Papua into Indonesia, the state development policies (New Order) were oriented to immigrants, covering Papuans access in order to obtain self-development. Consequently, there was an emptiness of private 'middle class' of indigenous Papuan (Timmer, 2007:610; Aditjondro, 2005). Secondly, Papuans are simply unable to compete with settlers in the rapid-growth sectors of the economy owing to an enormous gap in education and skill levels. Over 80 percent of Papuans have had only an elementary education; 62 percent of whom have not even passed elementary school (McGibbon, 2004:47). Thirdly, Papuan who tried to get involved in entrepreneurship activity were trapped in the dual economy. Many Papuan small traders have retained their traditional subsistence lifestyle, selling the surplus from garden crops grown primarily for domestic consumption. Papuans' customary beliefs (kinship system, land, prestige, etc.) give rise to an economy of exchange relations that serves as the basis for social interaction which is largely incompatible with a capitalist mode of accumulation (ibid:46). At the same time, these traders have had to compete with settlers in the marketplace who are strongly capitalist in orientation. They have developed exemplary networks between families, similar ethnic groups, or even inter-ethnics in expanding business (Akhmad, 2005).

The presence of Otsus Law for Papua emerges new political forces for themselves in economical contestation. ${ }^{1}$ Otsus Law forces the state to deliver a positive affirmative policy of Papuan society in assisting their position onto negotiation in obtaining resources in their own land (Widjojo et al, 2008). Jacques Bertrand mentions this tendency as 'political accommodation' when ethnic minorities such as Papuans are given institutional means of advancing their interests. Various institutional schemes allow ethnic groups to be represented and to advance their group interests through formal institutional channels (Betrand, 2007:17).

\footnotetext{
${ }^{1}$ Within Special Autonomy (Otsus) Law 2001 literally serves a new empowerment and strength for Papuans. Upon province official, Otsus Law presents an authority to generate comprehensive regulations, except foreign regulation, defense, finance and fiscal, religious and human right. At legislative level was formed DPRP and MRP in representing OAP (Papua Indigenous Society) on every single policy made by the government. Within financial sector Papua was given the privilege to obtain $80 \%$ of mining, forest, and fishery, and $70 \%$ of oil and gas. Jacques Bertrand, 2007, Papuan and Indonesian nationalisms: Can they be reconciled?
} 
Despite affirmative policy currently tends to appeal Papuans to get a job as government officials (McGibbon, 2004; Chauvel, 2007), yet it cannot be neglected there are numerous measures government had generated to encourage Papua to be able to compete among settlers ethnics in the market economy. In Jayapura, the most striking indication was the establishment of Mama-Mama Paриa marketplace in the business elite area where it brought tens of billions fund by the government recently. This market aims to accommodate traders of 'mama-mama' which previously selling on the fringe of the road.

Some policies which released after Otsus Law created the politics of economic spaces in Jayapura City became more interesting to re-investigate. This article intends to determine urban space dynamic of Jayapura based on Marxist-urbanism perspective, in which it offers a frame to figure out urban structure between classes variation, communities, ethnics, or territorial forms of identity and group belonging that compose both the fabric of everyday life and the patterns of capitalist investment and urban governance in space (Tajbakhsh, 2000:2). The economic spaces of the city that would be examined are the places that operating bazaar system (Geertz, 1989) which depends on three aspects; (1) the flow of goods and services; (2) the economic mechanism sequence that performs and controls goods and services flow; (3) the socio-cultural role of the market system. The intended economic spaces are private and informal sectors of the city such as central businesses, shops and distributors, traditional markets, peddlers, street vendors and networks within them.

Meanwhile, ethnic groups to be examined other than Papuans ${ }^{2}$ themselves are Chinese, Buginese, and Javanese. This consideration is based on several factors. Chinese, despite they just a minority, have gained exceptional position since the Colonial era until New Order as the middlemen traders among international trade (Garnaut dan Manning, 1979) that means they historically possess political and financial capital as well as modern economic habitus. Whereas Javanese and Buginese ethnics are the biggest non-Papuan migrants in Jayapura recently, both arrived by transmigration state's program as well as spontaneous migration (Ananta, 2016), are also considered the main actors upon the informal sector. Considering these four groups strategically can reveal the economic structure of Jayapura City based on ethnicity.

\section{RESEARCH METHOD}

Primary data was obtained from the urban ethnographic approach. Urban ethnography in this sense means urban walking or urban tour ethnography (Pink, 2008). 'Walking in the city' ethnography is different compared to usual walking, that is, one would explore all of his senses to observe, making note, taking photos towards relevant matters. Researcher gaze is significant to perceive 'what appears'. It considers a city as an empty landscape and then being arranged in term of socio-culturally and economy-politically. Likewise ethnography, participation made of this method became Jayapura dweller for about two weeks on the daily activities; visiting markets, shopping, making a conversation with merchants, having coffee together with fishermen, eating at small food stall (warung), walking through city sidewalk, stuck in the traffic, also taking public transport. We also conducted deep interviews toward relevant informants as shop owners, traditional market traders, and warung owners, as well as

\footnotetext{
2 In this paper, we position Papuans both from and outside Jayapura as an indigenous Papuan ethnic group, although we understand that there are identity differences such as Papuans from other islands as well as from coastal or highlands. This is due to an assumption that the fragmentation of identity that appears in Jayapura is more related to Papuans (amber) and Non-Papuans (komin), especially since the euphoria of 'the papuaness' strengthened after Special Autonomy.
} 
government representatives, which were categorized on ethnics background, particularly Chinese, Buginese, Javanese, Makassarese, and Papuans. Secondary data was gained by literature study for relevant information, such as books, journals, and mass media through the internet.

\section{Capital Intensive Economy and Central Business in Jayapura}

The medium and large scale economic activity in Jayapura mainly centralized in two areas namely Jayapura city and Abepura city. Historically, both urban areas were formerly the centers of old town Hollandia (earlier Jayapura) established by the Dutch government on the 1910s and then the Allies during the Pacific War around the coast of Yos Sudarso Bay. In order to avoid military forces, administration government official was placed in the hinterland and located in the midst way which connected military port and airfield in Sentani, namely Abepura district. The two cities were known as Hollandia Haven (Jayapura city) and Hollandia Binnen (Abepura) (Baharuddin, 2017). The economic growth and the urban crowd of Jayapura currently developed rapidly along with a route that connects two regions, even are separated by hilly roads.

Until today, Jayapura city has grown to be a center of economy of the region, even for the entire of Land of Papua. Several locations in the city center become the place of national and foreign corporations, such as in the Gurabesi area, Ahmad Yani street, Percetakan Negara street, or in Pasifik Permai street. On the Burgess' concentric circle model of urban social economy, (Yunus, 2005:127; Abdullah, 2006:31), whose location can be considered as central business district (CBD) of Jayapura, a district center of commercial activities and an area which holds the modern capitalist image of a city.

Along the path of Ahmad Yani street and Percetakan Negara street stand star hotels, banks, supermarket, fast-food restaurant, café, as well as government offices block. In the interspace, there are 'ruko' (shophouse) owned by individual and private. These areas can be said to be the landmark of Jayapura, besides it becomes the concentration place of goods and service trading activities, there are also Yos Sudarso Monument in the east and Masjid Raya Jayapura in the west as the endpoints of this continuum (Baharuddin, 2000:40). As the city center, the areas of Ahmad Yani and Percetakan Negara not only represent the economic power of capital intensive, but also symbols of state existence and domination of immigrants communities in Papua. While in the Pasifik Permai area (Dok II), located near east of Ahmad Yani street right in the banks of Yos Sudarso Bay, it is a complex elite of shophouses called Pusat Bisnis Jayapura (Jayapura Central Business) where Swiss Belhotel shows elegantly in the corner of this site. Along the shore, people may relax in cafés and enjoy the beauty of Jayapura city during the night. Those cafés names quite show that the owners are immigrants (mainly Sulawesians), such as Café Losari, Café Maros, or Café Pangkep.

From this business central point, capital-intensive commerce spread also throughout activities and settlement of Jayapura, whether towards the north area (Tanjung Ria and Base-G beach) or to the south (Entrop, Abepura, Waena). Along the Kelapa Dua street in Entrop we will encounter splendid shophouses with various goods and services, such as building material shop, grocery store, vehicles dealers, furniture, and so on. While Abepura is known as students city due, schools and campuses are concentrated in this area. This has led to the emergence of many warung, restaurants, boarding houses, shops, supermarkets, hotels, cinemas, and etc. Along the shaft road we may come across shopping centers which are everywhere; two Saga Mall, Ramayana Mall, and two Mega Department Store. 
Large-scale trade within economic centers of Jayapura and Abepura generally controlled by Chinese community (McGibbon, 2004:36), besides Buginese in the middle scale business. Rodd McGibbon recorded in 1996, a few numbers of Chinese (440 persons) in Jayapura historically dominated various large city commerces (ibid). There is no data shown a certain number of how many Chinese businessmen in Jayapura and how much is their capital flow. Chinese community members are about 1.000 family or approximately about 3.000 lives. $^{3}$ The overview of Chinese community role regarding the economy of the city can be seen through the statement of Jayapura Mayor who said that Chinese citizen is pretty dominant upon economic development. ${ }^{4} \mathrm{He}$ argues that $70 \%$ of the economic development of Jayapura derived from the business sector and Chinese entrepreneur has the main role, even has become the companion for small-middle scale business. Their loan and savings activity enhance the local bank financial growth, also money circulation within the city gets satisfactory. About $75 \%$ of domestic revenue originated from regional retribution and these large companies taxes. In the circulation of goods trade in Jayapura, Chinese businessmen generally dominate as distributors with large capital. Their businesses such as grocery stores, supermarkets, building materials stores, clothes store in their own shophouses that occupy strategic areas as in the central business district above.

The presence of large commerces within Jayapura city unable to separate upon the reality of Chinese trading existence in the past. During the transition sovereignty from Dutch to Indonesia, small Chinese enterprises had already established in Papua replaced European companies and preserved old trade relation (Garnaut dan Manning, 1979:55). Immigrants which were inclined after the Act of Free Choice (Pepera or Penentuan Pendapat Rakyat) in 1969 increased large companies investment by Chinese and other ethnics. Some large companies mainly Buginese (prominence between Grup Benteng Mas) in the latest 1960s and early 1970s. George Aditjondro mentioned about ten companies operated within the construction and trade sectors, delivered strong competition towards rapid Chinese business, all assets were more than 1 billion rupiahs (around US\$ 1 million) latest 1980s. Henceforth, some timber manufacturers of Sulawesi (Torajans) have been improved into great companies distribute saw wood and government office furniture, private business and private consumers (Manning dan Rumbiak, 1989:26).

Large system trade of the Chinese ethnic has established in this place since the Dutch colonial era disclosed Jayapura. Before and after Pacific War, Chinese ethnic position was the intermediary traders to meet Colonial logistic needs and performed exchange between local inhabitants as well, namely tobacco, textile and steel equipment (Garnaut dan Manning, 1979:16). Chinese settlement establishment history can be traced by a residence called Kam Cina (Chinese kampong), approximately 200 meters by Abepura chief office. They were distributor traders and retailers of smaller traders inside and outside the traditional market. Their shops occupying on strategic areas, such as in front of the Police Station of Abepura and District Court Office. All those shops located on the roadside, like Gerilyawan street and Sentani highway.

Whether Chinese or Buginese are considered as dominant actors within the large-scale economy of Jayapura. Papuans and Javanese in this sense are subordinate economically. For

\footnotetext{
3 https://www.liputan6.com, Prancis atau Ciko julukan warga Tionghoa di Papua (French or Ciko surname of Chinese in Papua) February, 16, 2016.

4 https://www.pasificpos.com, BTM: Warga Tionghoa berperan membangun ekonomi Kota Jayapura (BTM: Chinese rules in developing Jayapura economic), February, 9, 2016
} 
the middle scale ventures, Chinese and Buginese frequently establish partnership effectively (Akhmad, 2005: 86). The relationship between Chinese and Buginese emerge patron-client relationship, in which goods credit may improve business. Not all traders are able to perform this pattern, as it depends on trustworthy between retailers (Buginese) and distributors (Chinese). Chinese strong position economically generates Buginese traders rely on them. This dependence of Buginese traders happens since Chinese has more capital facility and has already been gained the contestation among distributors.

\section{The Dominance of Buginese Traders in Traditional Market}

An important site can be used to determine Papuan economic transformation and to analyze contestation among ethnics within small and middle scale commerce in Jayapura namely traditional market. As the traditional market is a knot of goods distribution flow all over the city and various suppliers from different ethnics, both immigrants or Papuan themselves; as an arena of contestation as well as social-economy integration.

Traditional markets of Jayapura namely Hamadi central market, Entrop market, and Inpres market at Tanjung Ria Dok IV, as well as Hamadi fish market and Mama-Mama Papuan market (Pasar Mama-mama Papua) that have been built recently. In Abepura, traditional markets are centralized in old market of Abepura and Youtefa market. Each market offers foodstuff, clothes, and household stuff. Hamadi Market is the central market where the city trading center appears. Yet, another significant traditional market is Youtefa Abepura market, in which plays as a supplier towards other smaller markets within Jayapura. The main commodities of traditional markets are agricultural products and fishery, and those two are originally supplied from Abepura market. Agriculture products in Abepura market such as rice, corn, yams, peanut, green beans and fruits of Abepura Market are delivered from low land of Yoka and highland of Tanah Hitam, even from transmigration districts as Skow, Koya, Arso, or Nimbokran. Fisheries come from Yotefa Bay and Depapre by Buginese, Makassarese, Butonese, and Papuan fishermen who send their fish to Abepura market and Hamadi market and then being distributed to other markets.

Ethnic fragmentation in the scale of financial capital and type of commodity in each traditional market is quite visible. In the Abepura market, the large-scale venture such as wholesale or distributor shops is managed by Chinese and Buginese. On the middle scale, market stalls are controlled also by traders from Sulawesi or Javanese, Madurese, and Minangs. Buginese sells clothes, grocery, glassware, and vegetables. Makassarese dominates in the sale of sea products and fish. Butonese sells toys, imitation stuff, and secondhand clothes. Some Javanese carries vegetables, chicken, or tempeh. Madurese offers vegetables and cart services. Minangs sells clothes and electronic devices. Meanwhile, on the lowest scale is occupied by Papuans women traders (mama-mama), mainly highlanders, selling small quantities of their garden products such as vegetables, yams, fruits, and betel nuts. They sit on the ground on the fringes of the market, in front of Buginese stalls as well as on the sidewalk.

The unbalanced economic structure between settlers and indigenous Papuans traders corresponds if we compare the number of both within traditional markets. According to the traders' numbers listed officially by Youtefa Apebura market management in 2016, there were 2.821 traders in total, 76\% were immigrants and 24\% were local traders (Suhartawan et al., 2017). Immigrants traders ethnics commonly are Buginese, Makassarese, Butonese, and Javanese. Whereas who is categorized as Papuans divided into some parts, some who originally come from Jayapura, and others who come from the outside of Jayapura namely Serui, Biak, Sorong, Nafri, Pegunungan Bintang, Wamena, Dani, Paniai, and Yahukimo. 
Even though there are several considerable settlers ethnics upon traditional markets of Jayapura, such as Madurese and Javanese, Buginese is still considered as the dominant traders. It thanks to their habit since they have established the market as a residence at once. Around Jayapura's traditional markets scattered the Buginese settlement, which makes them possess higher access than other groups. Buginese, who did not have a house around the market, will likely rent a house which closes to the market. This phenomena frequently seen around Abepura market and Hamadi fish market, Buginese sets up stalls and shops which also functionates as a family shelter. According to Pelly (Akhmad, 2005), this kind of settlement is deliberately built to preserve relations and social traditional manners of the ethnic group from their origin.

By situating the traditional market as a place of livelihood and home at the once, Buginese can easily carry out their commerce activities. Market settlement behavior also allows them faster to open the stalls, to manage the goods, as well as to get the consumers. Those who live outside the market area utilize their house as shops. This pattern applies commonly to Buginese migration culture in Papua as their adaptation means. Living in a market environment makes them easily get new ideas to maximize economic opportunities, such establish boarding houses for Bugis fellow who does not obtain a house or shop. Grouping based ethnic has a strong capacity to construct primordial and works as ethnic protection from outside pressure which may endanger their communities.

Common comprehension within Jayapura also recognizes market under ethnic domination mainly from Sulawesi. Youtefa Abepura market mostly consists of Buginese and Bonese, Hamadi market inhabited by Butonese, Hamadi fish market by Buginese, Tanjung Ria market by Butonese and Makassarese, while the Entrop market is inhabited by Buginese from Pangkep Sulawesi. Settlers domination from South Sulawesi in Jayapura's traditional market can be understood historically. Most Buginese, Makassarese, and Butonese from South and Southeast Sulawesi entered Papua as spontaneous immigrants after entrance limitation (quarantine) to the province during Dutch occupation was revoked since Pepera and after sea transportation networks (PELNI) towards Jayapura became regular in the early 1970s (Manning dan Rumbiak, 1989:26). Immigrants from Sulawesi massively and suddenly concentrated on small trade, carpentry, and transportation then introduced new consumption goods for Papuans in either urban or rural areas (McGibbon, 2004:24). Since then, immigration flow continuously followed by large numbers of Buginese traders and urban self-employed and poorer Makasserese in a wide range of low-income self-employed jobs (Manning dan Rumbiak, 1989:26) which later on controlled traditional markets until today.

Buginese and some other ethnics from South Sulawesi gave considerable contribution in economic development and money circulation and goods within Jayapura upon middle scale. Within traditional markets, Buginese traders have become a pioneer of goods distribution which subsequently being used by Jayapura people including Papuans. Buginese presented market commodities which previously unknown by Papuan community such as rice, sugar cane, spices, clothes, and electronic devices (Akhmad, 2005). In addition, Buginese also drew some members of Papuans to get involved within modern market economy when they buy garden products, fisheries, or forest products from Papuans to be sold in the markets.

Buginese domination towards traditional markets in Jayapura strongly relates to socialeconomical networks they have established. Their network covers the relationship between own kin, with other Bugis fellow, or also with other ethnics. Buginese market trading network to other ethnic groups depends on two main relations, namely towards Chinese as capital 
resources and distributor of goods from outside Papua, and towards Javanese and Papuans as agriculture products distributors around Jayapura. Buginese traders often take a loan from Chinese distributors such as Toko Sumber Makmur, Toko Tapas, or other agents to fund their venture or to fulfill their retail items. With Javanese or Papuans farmers, Buginese often plays a role as middlemen before the commodity is distributed to the marketplaces. Their central position as traders, retailers, market stalls owners, and middlemen makes Buginese hold strong domination within the traditional market of Jayapura.

\section{Javanese Farmers and Peddlers in Jayapura}

Most Javanese settlers in Jayapura work in formal sectors as middle class educated servants such as government officials and private office employee (Manning dan Rumbiak, 1989; McGibbon, 2004; Upton, 2009; Ananta et al, 2016). Yet in informal sectors, Javanese has been long obtained the role as agriculture product distributors. The commodities are coming from their own land in transmigration district of Jayapura such as Koya, Skow, and Arso, or Nimbokran.

Government's transmigration program in the 1970's was a fundamental rationale in constructing Javanese' market network in Jayapura recently. Javanese transmigrants in Jayapura have long been considered more successful compared to transmigrants in other places in Indonesia and other Papua (Garnaut dan Manning, 1974; Arndt, 1986). Since early years, Javanese had been planned to be farmers who would supply vegetables to the city. The central government also wished Javanese transmigrants may introduce agricultural technique and encourage agriculture commercialization towards Papuans. Report regarding transmigrants success was written by Peter Hastings in the Sydney Morning Herald newspaper in 1983 (Ardnt, 1986:170);

"Koya is quite an eye-opener. It is a huge area of neat intersecting roads, new houses with tin roofs, laid out in equally neat rows [...]. Most of the non-Irianese are Javanese settlers. Most arrived there last year [...]. At a packed meeting of settlement leaders I could not find one who wished to return to Java. Most, in fact, were trying to bring other family members to join them. The big attraction was the two hectares of land the first they had ever owned - to which they had been given title. The usual arrangement is a quarter hectare for house and private garden and the remainder for crop culti-vation. In the fields I saw rice, soybean, peanuts, chilies, cucumbers, green beans and tomatoes."

Regarding the success of Javanese farmers, Gamaut and Manning (1974) argue that transmigrants peasants were more able to utilize market opportunities and get involved in government programs rather than indigenous Papuans. At Dosay, transmigration village near Sentani, Javanese has formed four cooperative units selling their vegetables into markets within Jayapura, yet there was not a similar cooperatives activity among indigenous Papuans. Indicators of Javanese expansion in the market economy of Jayapura was also shown in 1971 when only four indigenous among twenty people had ever rented tractors provided by the government and no Papuan had applied for agricultural credit from the regional development bank (ibid).

Until today, Koya, Arso, and Skow still remain the fertile agricultural districts. Those areas have become the enclaves of Javanese settlements with high population growth. At Arso of Keerom, the regency south of Jayapura, the population was less than 1000 lives in 1970's, but in 2000's had inclined to about 20.000 lives (Rumbiak in McGibbon, 2004). At Koya, once we enter this area we may notice the Javanese language is frequently spoken compared to Papuan language. 
Everywhere we could find fruit shops that offer agriculture products from local gardens. However, most of the agricultural products such as vegetables, nuts, fruits, eggs, or chicken are intended as commodity supplies for central markets in Youtefa Abepura or Hamadi. The results of it successful business can be seen through transmigration settlements throughout Koya main road, there are plenty of two-floored shophouses, urban modern houses, and newest motorcycles or cars back and forth here and there.

Commodities delivery process from transmigrant villages towards traditional markets in the city commonly conducted by several ways; delivered by farmers with their own vehicle, took by public transportation, or even bought by middlemen (tengkulak) who come by 'pick-up' car. Middlemen or intermediary traders are usually from Buginese ethnic, besides minority number consisted of Madurese, Makassarese, or Javanese themselves. It is rare that these middlemen come from local Papuans. Some Buginese traders on traditional markets choose to buy commodities directly in Javanese transmigrant villages in order to get cheaper prices compared to intermediary traders service. The Intensive relation between Buginese and Javanese ethnics groups upon trade networks often create a marriage between them (Akhmad, 2005:92).

Javanese also extends traditional market trade system by becoming mobile vegetable peddlers. Compared to other ethnic groups, only Javanese dominate this venture. They peddle vegetables by traveling around the city of Jayapura, as is commonly found in the cities of Java. Javanese Peddlers using various vehicles such as carts, motorbikes, or even pick-up cars. They bring commodities from traders of central markets such Youtefa Abepura and Hamadi since the dawn. This transportation means similar to a 'moving market', contains snacks for breakfast and vegetables, also fish for lunch. Then they will turn around in middle-class houses by yelling or honking several times while selling, so moms would likely notice they have come and no need to go to the market.

Outside the traditional market commerce, the small informal sector of Jayapura was also controlled by Javanese as street traders or street vendors. Recent years, street vendors (mainly food) have grown numerously, occupying crowd corners and roads both in Jayapura or Abepura. ${ }^{5}$ In Jayapura city, street trade activities are found in artery road such as Ahmad Yani, Percetakan, near Polda (regional police headquarters), or Entrop. At Abepura, food street vendors are concentrated in the crowd namely in front of Saga Mall, Biak street, Gerilyawan street, or around Universitas Cendrawasih campus in Waena district. In front of the Buginese or Chinese shophouses throughout these roads are full of many kinds of vendors using semipermanent tents, and it becomes crowded when evening comes and after shops are closed.

The domination of Javanese (and small number of Madurese) migrants in this field can be recognized from the food they sell. Throughout Percetakan street next to Polda appears many semi-permanent tent vendors selling Javanese food such ayam bakar, pecel lele, soto Lamongan, sate Madura, bakso, nasi goreng, bakmi, and etc. in the afternoon. Furthermore, there is also Javanese sell Papuan food like sago cake, papeda, or Sulawesian dishes. Stalls' names also indicate their Javanese features such as Warung Pak Kumis, Warung Bu Atmo, Warung Pakdhe, or Warung Surabaya. This small-scale economic sector cannot be seen as trivial business since it has a considerable money circulation. As Jayapura mayor said, "Outsiders (non-Papuans) observe Papua or specifically Jayapura has its own attraction, even though one just selling fried

5 https://www.pasificpos.com, BTM: Warga Tionghoa berperan membangun ekonomi Kota Jayapura (BTM: Chinese rules in developing Jayapura economic), February, 9, 2016 
bananas (pisang goreng) it is not a petty business, start in the morning until noon may obtain 5 to 10 million a day, the profit is extraordinary, bakso vendors and any kind of sellers in Jayapura can get a high amount of money..." (Al-Makassary, 2014:17). Similar to other cities in Indonesia, informal sector such street vendors are pretty influencing towards Jayapura's economy, despite large-scale business and traditional markets.

\section{The Barriers in entrepreneurship of Indigenous Papuans}

Chinese, Buginese, and Javanese economic activities indicate that settlers (amber) dominate informal sector spots within Jayapura compared to indigenous Papuan themselves (komin). Of course there are Papuan entrepreneurs involved in the capital intensive business although the numbers are still very little. Meanwhile Buginese, Torajans, Bataks, as well as the huge capitals coming from Java began to reach the level of business equivalent to Chinese.

It has been long that some efforts made in many sectors to improve Papuans entrepreneurship, but that development always hampered by many issues. After the Pacific War, Dutch authority supported the economic independency of Papua as a means to obtain sympathy of Papua. The Dutch controleurs was placed in the highland villages tried to enhance the domestic economy. On the south coast, some trade activities were being developed by Dutch at Manokwari land and Hollandia (Jayapura). ${ }^{6}$ Nevertheless, after Indonesia had taken over the authority, several subsectors of this grassroots economy were taken over and distributed through state and private agents. For instance, a timber company in Holtekang Jayapura that was established from the rest funds of UN development programs for Papua was later controlled by capitals from Jakarta and became PT. Hanurata Co. Ltd. There was a shift in orientation from indigenous Papuan development to outsiders Non-Papuan development (Aditjondro, 2005:xix). This situation might be one of the main reasons that the entrepreneurship of Papuans did not growth effectively. Coupled by the huge presence of immigrants from Sulawesi and Java immigrants fulfilling manual workers and small business opportunities, making the absence of indigenous Papuan middle class (Timmer, 2007:610).

Small economic development projects still continued by the local government. In the 1970 s Governor of Irian Jaya declared a regulation which was to subcontract small construction projects upon local businessmen, even though later dealt with laborers flow and migrants entrepreneur with good skills and more experienced. Contractors prefer to employ what they regard as more reliable, harder working migrant labor. Many Papuans are reported to work short periods for target incomes and remain tied to traditional agricultural patterns, returning to their villages after short periods of wage employment. (Manning dan Rumbiak, 1989:27).

The historical and political obstacles caused Papua left-behind in term of entrepreneurship, the lack of skills, and have not fully integrated with the system of market economy widely. This pattern will likely be found if we try to compare towards urban economical spaces which are managed by settlers. Chinese basically owning stores or shophouses around market main roads. Buginese and their Sulawesians compatriots, Javanese, as well as Madurese occupying market blocks. While Papuans sell their goods by sitting on the ground at the market fringes. It is simply because staying outside the market is cheaper, as traders they only require to pay market retribution rather than pay for stall rent each month to the government.

\footnotetext{
${ }^{6}$ In the southern Papua, high-branched paddy was introduced in Merauke, along with the deer of Timor. At Digoel river, rubber was introduced as a suitable commodity plan towards ecosystem, due to conform Auyu tribe culture as hunters and gatherers (George J. Aditjondro, 2005, Meneropong Lubang Puser Sendiri: Kendala-kendala dalam penelitian di komunitas sendiri, page. xix).
} 
Papuan traders lay their goods on the land using plastic pad or carton. Mostly they come from the countryside near the market, and some others are coming from distant villages, namely Nimbokran, Genyem, Besum, Demta, and Sentani. They offer tomatoes, chilies, beans, cabbages, papaya and cassava leaves, sagos, corns, pineapples, oranges, matoas, bananas, yams or another vegetable from their gardens. Traders coming from coastal area bring fish. They carry just few goods to market. Generally, very few of Papuans sells goods from outside Jayapura such as clothes, toys, glassware, furnitures, or electronic machines. Even Papua traditional craft in Hamadi market is sold by Buginese. Whereas vegetables and fish commodities are not only sold by Papuans, but also Buginese, Javanese, Madurese with a larger amount. Papuan do not have any commodity specialization, compared to settlers who obtain networks, experiences and bigger assets, make Papuans being marginalized within the traditional market economy.

Outside the traditional market, the situation is nothing really different. As far as our observation, almost no Papuans have their own shops or grocery. Even if they work in a shop, they are only as shopkeepers or employees of Buginese or Chinese owners. Papuans' farming is not concerned mainly with agricultural commodities or industries as Javanese transmigrants farming. Their commodities are the surplus of domestic consumption. Garden or fishing yields basically for the family needs, and if there is a more then the women (mama-mama) would likely sell it in the market. The profit from selling commodities will be used for household needs such as rice, fish, oils, petrol, and spices. If family needs were fulfilled, they would likely not go to the market. It means they obtain little will in accumulating money. Garden yield is carried by themselves or sometimes bought by middlemen of Javanese and Buginese who come to the village. There is no Papuan occupying a central position as commodity intermediary traders or peddlers. In the business of street merchants, Papuans basically have appeared along with settlers traders. But a quite visible difference is for both that the Papuan street traders mostly sell goods for Papuans consumption themselves, such as betel nuts or noken bags. Throughout the main road of Abepura to Jayapura, we will find mama-mama offer betel nuts on the sidewalk.

One of the arguments relating to Papuans role in the informal sector is trading activities are not main life orientation, but an extension of their subsistence lifestyle (Akhmad, 2005). Trade activity of Papua tends to be "there is money, there is goods", their trade pattern is quite simple, it does not go through complicated networks and capital loan, or in other words, their economy is an immediate exchange (ibid:108). The pattern of immediate exchange economic is still dominant within the Melanesian culture, in which the process of exchange performs a central social function in establishing and maintaining reciprocal obligations within the community. In traditional Papuan societies, exchanging pigs or other commodities is central in resolving conflicts, forming clan and family alliances, securing marriage rights, and so on. In such belief systems, there is little benefit in accumulating capital. Social prestige and advance come with exchanging goods, not accruing capital. Papuans' customary beliefs give rise to an economy of exchange relations that serves as the basis for social interaction which is largely incompatible with a capitalist mode of accumulation. Unless Papuans reconcile traditional beliefs with modern necessities, it is difficult to see how indigenous economic mobility will occur in Papua. Efforts to promote capital accumulation among Papuan traders, through creation of small stalls, for example, have met with little success (McGibbon, 2004:46-47).

Hence, many Papua traders preserve their subsistence lifestyle, at the same time, they have to compete against settlers who possess extensive capitalist orientation. This is compounded by the lack of Papuans' trade networks and tends to orients internally, as seen the goods they sell for Papuans interests. Unlike Chinese, Buginese, and Javanese which make relations to each 
other in widely trade partnership, consequently it strengthen the position of amber in Jayapura.

\section{Affirmative Politics Towards Papuan Traders}

The will to improve indigenous fate in Jayapura strengthened after Otsus era. There were efforts made to carry Papuans within economical contestation all over aspects, both large-scale or small-scale traders. On the intensive-capital economic level, the government has given a flexibility opportunity for Papuans to become entrepreneurs or establishing companies which may develop the economic opportunity. One of them is Presidential Regulation Number 84 of 2012 About Procurement of Goods/Services in Accelerating Development of Papua and West Papua Province, in order to deliver the bigger chances and roles for indigenous Papuan to manufacturing goods/services over the province (Al-Hamid, 2015; Marit, 2017:8). In addition, in 2006 Jayapura the local government had established Kamar Adat Pengusaha Papua (KAPP) or Indigenous Chamber of Papua Entrepreneurs, as an entrepreneur organization of for the indigenous Papua. However, in fact, more Papuan entrepreneurs get involved in micro business and very few made in large-scale business. ${ }^{7}$ Their business level is more to survival manners and has to deal with struggles to obtain capital in order to improve their business. ${ }^{8}$

Within traditional markets trading, the local official had been attempted to cope social gaps between indigenous and settlers upon markets. In the 2000s there was a policy to establish market blocks intended only for Papuans. In Abepura market, once there were two blocks appointed for Papua for vegetable spots. But what happened later, those blocks were abandoned and sold to Non-Papuan traders. Papuan traders then returned to the sidewalk or in the bus station. In order to overcome this matter, the government had already built a new market known as Pasar Rakyat Entrop (Entrop people market) that aimed to be occupied by traders of indigenous Papuan. It has 368 stalls, 48 stalls for indigenous. As to prevent the previous issue re-occur, one of the rules says that each stall is forbidden to be sold.

The most appealing affirmative politics for Papuans economy is the establishment of Mamamama Papua market. This market was built decently with four floors located in central business district of Jayapura as mentioned above, namely at Percetakan Negara street. This market spent about 30 billion from State Owned Enterprises (BUMN) and supported by Presidential Staff Office and Indonesian state-owned enterprises ministry, which ables to accommodate 298 merchants. ${ }^{9}$ Previously, mama-mama traders offered their goods using carton over sidewalks and on the parking lot of Galael Supermarket and KFC restaurant on the fringe of Percetakan Negara street. An ironic description regarding the clash between traditional Papuan economy and the global market economy represented by Galael and KFC once written by I Ngurah Suryawan few years ago:

"In the midst of 2010, I visited Galael market of Jayapura. From the afternoon until the night I noticed the activities of mama-mama Papua peddling their goods. From noon, Mama-mama Papua were coming from everywhere started occupying Galael yard. The first floor is a supermarket, and the second floor is the exclusive KFC restaurant. Mama-mama Papua arrived carrying goods such as vegetables, betel nuts, fruits,

\footnotetext{
7 https://suarapapua.com, Pengusaha Non-Papua kuasai Pengerjaan Infrastruktur di Papua (Non-Papua businessmen control Infrastructure establishment in Papua) August 20, 2017

8 http://tabloidjubi.com, KAPP: Ribuan Pengusaha Papua Kesulitan Mendapatkan Kredit (Thousands of worker of Papua struggling in obtaining loan) April 20, 2017

9 https://haipapua.com, Berjuang sejak 2009 Akhirnya Mama-mama Papua bisa menempati pasar sendiri (Struggling since 2009 Finally Mama-mama Papua can occupy its own market) February 20, 2018
} 
patatas, yams, and so on. They were carrying their goods inside the sacks, that mamamama started to hold a mat and simple pad then later put out their goods on the ground. Most of them began to sort out their goods from the sacks and rolled out them into smaller pieces. While I saw civil servants in uniform went in-out of Galael supermarket and KFC. They went shop for a long time at the supermarket. Some people were seen having conversations in KFC" (Suryawan, 2013:98).

Suryawan had commented that the presence of the Special Autonomy Fund has not been able to present the partiality towards the struggle of mama-mama Papua to gain the market facilities (ibid:101). But now, a decent modern market possessed by mama-mama Papua only, not for Buginese, Javanese or other traders. They no longer roll out the mat on the fringes of the roads but in a clean, healthy, and tidy place. Their place is no longer facing the modern supermarket, but right in front of the Aston hotel, one of the most luxury hotel in Jayapura, with a modern image and located in city central business district. This market is a symbol of the efforts to revive the Papuans economy from certain actors after Special Autonomy, either from state government or Papuans themselves. From the central government, market establishment represented the presence of state upon Papua economical development, which for decades has been pushed through the Otsus Law. Even President Joko Widodo has visited the market several times. For Papua society, particularly mama-mama, this market is a symbol of their success in demanding a place upon Jayapura's economy, which was marginalized for decades. The presence of Otsus become a 'space' for mama-mama Papua to struggle for their identities (ibid).

The next possible question is do the state's accommodative policy towards Papuans in the Jayapura market economy has been effective in improving their prosperity? it is too early to measure the effects of indigenous economic development. In its current condition, the economic structure between settlers and indigenous Papuan in Jayapura seems not too different from the previous time, even since the Pacific war Era. Chinese community still dominates the large-scale trade, followed by Buginese and Javanese in the middle and smallscale. Those three ethnic groups are main players of Jayapura's market economy, where the Papuans are still on the lowest level. However, the difference today is that Papuans holding new powers to renegotiate their positions in the city's economic structure since they control the realm of identity politics after the Special Autonomy era.

\section{CONCLUSIONS}

This research attempts to explain why amber and komin sentiment still appears strongly within Jayapura society. By observing on the situation Jayapura's informal economy spaces after the Otsus era, we argue that it was caused by the economic structure of Jayapura has not really changed since the colonial era and before Otsus era. In large-scale commerce spaces such the central business of Jayapura, Chinese businessmen, as well as national and international companies, still hold the domination. In the middle economic spaces such as shophouses, groceries, and goods distributors, is also still controlled by this ethnic group despite having a small population. In public spaces where to sustain the city economy such as traditional markets and fishery, Sulawesi migrants particularly Buginese is the most dominant, includes the middlemen who buy items from Javanese and Papuan farmers. Within commodities distributors of the central market, transmigrant farmers are quite dominant, even though Papuan farmers and fisherman also participate in the small scale. Upon small spaces contestation of the city, Javanese is more dominant utilizing several mobilities such vegetable peddlers or street vendors. Papuans (both outside and inside Jayapura) basically also involve in the market trade, farming, or fishing. But, their venture has not been developed efficiently, 
since historical and political made them lack commercial experiences and they have not developed inter-ethnic business networks as settlers. In addition, the ties of traditional customs and subsistence lifestyles remain appears and become obstacles to their integration towards the market economic system.

However, the Special Autonomy Law provides a symbolic 'victory' of the 'defeated' of Papuans in practice. The establishment of Mama-mama Papua market by the government is a clear example, despite another policy which encourages Papuans to expand their entrepreneurship and the provision of commercial spaces. Until now, the indication of Papuans can get out of the subordinate position in the Jayapura's economic context has not appeared yet, but the presence of affirmative policy we may hope that Papua itself will be the main economic player in their own land. That way, amber and komin sentiment may be minimized.

\section{References}

Abdullah, Irwan. (2006). Konstruksi dan Reproduksi Kebudayaan. Yogyakarta: Pustaka Pelajar

Aditjondro, George J. (2005). Meneropong Lubang Puser Sendiri: Kendala-kendala dalam penelitian di komunitas sendiri. Forewords in Akhmad. Amber dan Komin: Studi Perubahan Ekonomi di Papua (p. ix-xx). Yogyakarta: Bigraf Publishing

Akhmad. (2005). Amber dan Komin: Studi Perubahan Ekonomi di Papua. Yogyakarta: Bigraf Publishing

Al-hamid, Idrus, I. Abdullah, dan Z. Bagir. (2013). Local Politics and Religion. Journal of Government and Politics. Vol.4 No.2 August 2013

Al-Makassary, Ridwan. (2014). Preventing Communal Conflict in Jayapura, Papua, Indonesia: An Early Warning System (FAST) Approach.

https://www.academia.edu/11672801/Preventing_Communal_Conflict_in_Jayapura_Papua_Indonesia_An_Early_ Warning_System_Approach

Al-Makassary, Ridwan. (2014). Peta Kekerasan khususnya kriminalitas di Kota Jayapura Berbasis SNPK. Jayapura: PePeDa Institute dan The Habibie Center

Arndt, H. (1986). Transmigration to Irian Jaya. In R. J. May, (ed.). Between Two Nations: The Indonesia-Papua New Guinea Border and West Papua Nationalism. Bathurst, NSW: Robert Brown and Associates.

Ananta, Aris, W. Utami, dan B. Handayani. (2016). Statistics on Ethnic Diversity in the Land of Papua, Indonesia. Asia \& the Pacific Policy Studies. Vol. 3. No. 3. p. 458-474

Baharuddin, Alfini, B.H. Wibisono, B. Prayitno, dan M.S. Roychansyah. (2015). Heterogenity of Amber and Komin in Shaping Settlement Pattern of Jayapura City. Komunitas. Vol 7. 2th edition 2015. p. 226-337

Baharuddin, Alfini. (2000). Studi Penataan Konfigurasi Bangunan pada Koridor Jalan Ahmad Yani Jayapura. Surabaya: Graduate master thesis in the Architecture Study Program Institut Teknologi Sepuluh Nopember Surabaya year 2000 .

Barth, Fredrik. (1988). Kelompok Etnik dan Batasannya: Tatanan Sosial dari Perbedaan Kebudayaan. Jakarta: UI Press

Bertrand, Jacques. (2007). Papuan and Indonesian Nationalisms: Can They be Reconciled?. Dalam Eva-Lotta E. Hedman (ed). Refugee Studies Centre Working Paper No. 42, Dynamics of Conflict and Displacement in Papua, Indonesia (p. 16-31). September 2007. Oxford: Department of International Development University of Oxford

Chauvel, Richard. (2007). Refuge, displacement and dispossession: responses to Indonesian rule and conflict in Papua. Dalam Eva-Lotta E. Hedman (ed). Refugee Studies Centre Working Paper No. 42, Dynamics of Conflict and Displacement in Papua, Indonesia (p. 32-51). Oxford: Department of International Development University of Oxford, p. 32-51

Garnaut, R. and Manning, C.. (1979). Perubahan Sosial Ekonomi di Irian Jaya: Integrasi ke dalam Kawasan Indonesia dan Pembangunan Ekonomi. Gramedia: Jakarta.

Geertz, Clifford. (1989). Penjaja dan Raja: Perubahan Sosial dan Modernisasi Ekonomi di Dua Kota di Indonesia. Jakarta: Yayasan Obor Indonesia 
Akhmad, Tanjung, R. H. R., Poli, A. I., Ali, A., \& Kumoro, N. B. (2019). Ethnicity, Identity, And The Politics Of Space In Urban Society Of Jayapura City. Advances in Social Sciences Research Journal, 6(2) 383-399.

Jones, Paul. R dan Ninik Suhartini. (2014). Reframing Approaches to Conceptualising Urban Governance in Melanesia: Insights from Jayapura and Port Moresby. Jurnal Perencanaan Wilayah dan Kota. Vol. 25. No. 2. August 2014. p. 96-114.

Koentjaraningrat, dkk. (1994). Irian Jaya: Membangun Masyarakat Majemuk. Jakarta: Djambatan.

Lamba, Arung. (2011). Kondisi Sektor Informal Perkotaan dalam Perekonomian Jayapura-Papua. Jurnal Ekonomi Bisnis. Year 16. No. 2. July 2011. p. 155-161.

Manning, Chris dan M Rumbiak. (1989). Economic Development Migrant Labour and indigenous welfare in Irian Jaya 1970-84. Canberra: National Centre for Development Studies, Research School of Pacific Studies, The Australian National University

Marit, Lenny Elisabeth. (2017). Toponimi Badan Usaha di Era Otsus Papua: Analisis Nilai Ekonomi, Sosial-Budaya, dan Politik di Kota Jayapura. MELANESIA: Jurnal Ilmiah Kajian Sastra dan Bahasa. Volume 01. Number 02. February 2017. ISSN: 2528-4258.

McGibbon, Rodd. (2004). Plural Society in Peril: Migration, Economic Change, and the Papua Conflict (Policy Studies 13). Washington: East-West Center Washington. Diundul di www.eastwestcenterwashington.org/publications

Pink, Sarah. (2008). An Urban Tour: The Sensory Sociality of Ethnographic Place-Making. Ethnography. Los Angeles: SAGE Publications. http://www.sagepublications.com Vol 9(2): 175-196[DOI:

10.1177/1466138108089467]

Suhartawan, Viva V, AM Ridjal, I Martiningrum. (2017). Toleransi Pedagang Lokal dalam Aktivitas di Pasar Tradisional Youtefa, Abepura. Jurnal Mahasiswa Jurusan Arsitektur Universitas Brawijaya Malang. Vol. 5, No. 1 year 2017 http://arsitektur.studentjournal.ub.ac.id

Suryawan, I Ngurah. (2013). Papua Pascakolonial: Jejak Kolonial, Pentas Representasi Identitas, dan Kuasa Kapitalisme Global. Tifa Antropologi, Jurnal Ilmiah Etnografi Papua. Vol. 01. No. 01 July 2013.

Tajbakhsh, Kian. (2000). The Promise of the City: Space, Identity, and Politics in Contemporary Social Thought. Barkeley: University of California Press

Timmer, Jaap. (2007). Desentralisasi Salah Kaprah dan Politik Elite di Papua. In Henk S Nordholt dan Gerry van Klinken (ed). Politik Lokal di Indonesia. Jakarta: Yayasan Obor Indonesia dan KITLV-Jakarta

Tirtosudarmo, R. (2014). Migrasi dan Etnisitas di Kaimana, Papua Barat. Jakarta: Paper seminar, Tim Kajian Papua LIPI and Jaringan Damai Papua (JDP)"

Upton, Stuart. (2009). The Impact of Migration on The People of Papua, Indonesia: A Historical Demographic Analysis. New South Wales: Dissertaton in Department of History and Philosophy University of New South Wales January 2009

Widjojo, M. S., A. Elisabeth, Amiruddin, C. Pamungkas, dan R. Dewi. (2009). Papua Road Map. Jakarta: Yayasan Obor Indonesia, LIPI, Yayasan Tifa.

Yunus, Hadi S. (2005). Manajemen Kota: Perspektif Spasial. Yogyakarta: Pustaka Pelajar

\section{References from the Internet:}

"Perancis atau Ciko: Julukan Warga Tionghoa di Papua" in https://www.liputan6.com/regional/read/3291960/prancis-atau-ciko-julukan-warga-tionghoa-dipapua (accessed on August, 14, 2018)

“Akhirnya Pasar Mama-Mama Papua Diresmikan” in https://www.papuatoday.com/2018/03/08/akhirnyapasar-mama-mama-papua-diresmikan/ (accessed on August, 14, 2018)

"Akhirnya Mama-Mama Papua bisa Menempati Pasar Sendiri” in https://haipapua.com/berjuang-sejak-2009akhirnya-mama-mama-papua-bisa-menempati-pasar-sendiri/ (accessed on August, 14, 2018)

"Pasar Mama-Mama Papua ini Sebenarnya untuk Siapa" in http://www.tabloidjubi.com/artikel-18550-pasarmamamama-papua-ini-sebenarnya-untuk-siapa-.html (accessed on August, 14, 2018)

"Menjamurnya Pedagang Kaki Lima di Kota Jayapura" in https://kabarpapua.co/menjamurnya-pedagangkaki-lima-di-kota-jayapura/ (accessed on August, 15, 2018) 
"Pengusaha Non-Papua Kuasai Pengerjaan Infrastruktur di Papua" in https://suarapapua.com/2017/08/20/pengusaha-non-papua-kuasai-pengerjaan-infrastruktur-di-papua/ (accessed on August, 14, 2018)

"KAPP: Ribuan Pengusaha Papua Kesulitan Mendapatkan Kredit" in http://tabloidjubi.com/artikel-5614-kappribuan-pengusaha-papua-kesulitan-mendapatkan-kredit.html (accessed on August, 14, 2018)

"BTM: Warga Tionghoa Berperan Membangun Ekonomi Kota Jayapura" in https://www.pasificpos.com/item/8051-btm-warga-tionghoa-berperan-membangun-ekonomi-kotajayapura (accessed on August, 14, 2018) 